\title{
PENINGKATAN HASIL BELAJAR POKOK BAHASAN PERTUMBUHAN TANAMAN DENGAN METODE PEMBELAJARAN KONTEKSTUAL SISWA KELAS X SMK BALLA KABUPATEN MAMASA
}

\author{
Elisaberth Rambulangi*) \\ Email: elisaberth69@gmail.com \\ *) SMP/SMK Balla Kabupaten Mamasa Sulbar
}

\begin{abstract}
Abstrak
Penelitian ini merupakan subjek subjek pertumbuhan tanaman kelas Biologi X SMK Balla. Penelitian tindakan dilakukan dalam dua siklus, siklus pertama dan siklus kedua. Populasi dan sampel penelitian ini, semua siswa kelas X sebanyak 18 orang. Data diambil dari hasil uji formatif, baik pada siklus I maupun siklus II. Teknik analisis data yang dilakukan bersifat deskriptif kualitatif. Hasil penelitian menunjukkan bahwa penguasaan pembelajaran pada siklus I sangat rendah hanya $28 \%$ dan $72 \%$ tidak lengkap. Kemudian setelah melalui pembelajaran kontekstual di kebun percobaan, pelaksanaan siklus kedua, menunjukkan perbaikan yang signifikan, yaitu 83,3\% siswa yang menerima selesai dan sisanya $16,7 \%$ belum lengkap, sehingga dapat disimpulkan bahwa pembelajaran kontekstual metode untuk meningkatkan hasil belajar subjek subjek pertumbuhan tanaman kelas Biologi X SMK Balla.
\end{abstract}

Kata kunci: Pembelajaran Kontekstual mengenai Pertumbuhan Tanaman.

\section{Abstract}

This research is a classroom action research aims to improve learning outcomes subject of plant growth subjects Biology class X SMK Balla. Action research was conducted in two cycles, the first cycle and the second cycle. Population and sample of this research, are all students of class $X$ as many as 18 people. Data taken from the results of formative tests, both in the first cycle and the second cycle. Data analysis technique conducted a qualitative descriptive. The results showed that mastery learning in the first cycle is very low at only $28 \%$ and $72 \%$ incomplete. Then after going through contextual learning in experimental garden, the implementation of the second cycle, showed significant improvements, ie $83.3 \%$ of students who received grades completed and the remaining $16.7 \%$ is not yet complete, so it can be concluded that the Contextual learning methods to improve learning outcomes the subject of plant growth subjects Biology class X SMK Balla.

Keywords: Contextual Learning on the subject of Plant Growth.

\section{PENDAHULUAN}

Salah satu mata pelajaran yang terdapat dalam kurikulum SMK 2013 yang telah direvisi pada tahun 2016 untuk bidang keahlian Agribisnis Tanaman dan Hortikultura, adalah mata pelajaran Biologi. Mata pelajaran ini, termasuk dalam mata pelajaran Kelompok C (Peminatan), dengan sub kelompok $\mathrm{C} 1$ yaitu mata pelajaran Dasar Bidang Keahlian. Mata pelajaran ini, diajarkan kepada siswa Kelas X baik pada Semester I maupun pada Semester II, dengan alokasi waktu 4 jam pelajaran setiap minggu. Salah satu pokok bahasan dalam mata peajaran ini, adalah Pertumbuhan Tanaman. Pokok bahasan ini diajarkan secara teori di dalam kelas, namun agar lebih mudah dipahami dilakukan praktek di kebun percobaan dengan melakukan percobaan dengan tanaman tomat (Solanum lycopersicum), dengan menggunakan pupuk sebagai perangsang pertumbuan tanaman. Mengapa mempergunakan tanaman tomat (Solanum lycopersicum), karena tanaman ini mudah tumbuh dan dapat 
diamati dalam waktu yang tidak lama, serta mempunyai nilai ekonomis serta sangat dibutuhkan oleh masyarakat secara umum untuk menunjang gizi keluarga. Disamping itu, para siswa diharapkan dapat mempraktekkan pengalamannya di rumah dalam rangkah membantu kebutuhan ekonomi keluarga, dan tidak tertutup kemungkinan menjadi salah satu usaha ekonomi kreatif di tengah-tengah masyarakat mengingat tanaman ini sangat dibutuhkan semua orang.

Kemampuan guru untuk mempergunakan metode mengajar yang tepat sangat berpengaruh terhadap peningkatan hasil belajar siswa. Kemampuan siswa dan mutu pembelajaran di sekolah dapat dikembangkan dengan melibatkan peserta didik secara aktif sehingga terciptalah pembelajaran kontekstual. Pembelajaran kontekstual adalah pembelajaran yang terpusat pada peserta didik. Belajar konteksual membantu para siswa untuk mendengar, melihat, dan mempraktekkan secara langsung dan nyata materi pelajaran tertentu, dan dengan pengalaman nyata di lapangan para siswa dapat mendiskusikannya dengan teman yang lain di kelas. Salah satu indikator pembelajaran kontekstual dapat dilihat dari keaktifan siswa ketika dapat melaksanakan secara nyata teori yang didapatkan di kelas. Mata pelajaran Biologi adalah salah satu mata pelajaran, walaupun termasuk sains murni, tetapi ada banyak pokok bahasan yang dapat dilaksanakan secara kontekstual di lapangan, salah satunya adalah pokok bahasan pertumbuhan tanaman yang juga sangat menunjang keahlian siswa khususnya siswa SMK Pertanian.

$$
\text { Jumnati (2013) mengatakan }
$$

bahwa: " Hasil belajar adalah kemampuan yang dimiliki oleh siswa setelah belajar, yang wujudnya berupa kemampuan kognitif, afektif, dan psikomotor. Derajat kemampuan yang diperoleh siswa diwujudkan dalam bentuk nilai hasil belajar" Berdasarkan pendapat ini, untuk meningkatkan hasil belajar berarti seorang guru harus mampu meningkatkan kemampuan kognitif, afektif, dan psikomotor siswa setelah ia melakukan suatu proses belajar. Prestasi meningkat bukan hanya dambaan setiap siswa maupun orang tuanya, tetapi seorang guru pun memiliki harapan akan peningkatan prestasi belajar siswa yang dibinanya. Akan tetapi tidak banyak guru memiliki ilmu atau kemapuan tentang strategi peningkatan prestasi belajar siswa.

Pola belajar adalah rangkaian prosedur dalam belajar yang dapat membantu siswa dalam menguasai pelajaran. Pola balajar diantaranya pola belajar mandiri, pola belajar terbimbing, pola belajar kelompok, pola belajar diskusi dan lain-lain. Masing-masing pola belajar tersebut memiliki kelebihan dan kekurangan. Dalam pelaksanaanya pola belajar mandiri telah biasa dilakukan oleh siswa di rumah masing-masing Sriyono (dalam Roestiyah,2000:106).

Dari pendapat diatas, dapat disimpulkan bahwa pola belajar adalah rangkain prosedur dalam kegiatan belajar mengajar yang nantinya akan mampu membantu siswa dalam kegiatan belajar mengajarnya. Oleh sebab itu, proses untuk mempelajari hal yang baru akan lebih efektif jika siswa dalam kondisi aktif, bukannya reseptif. Salah satu cara untuk kondisi pembalajaran seperti ini adalah dengan menstimulir siswa untuk menyelidiki atau mempelajari sendiri materi pelajarannya melalui pembelajaran kontekstual di lapangan.

Menurut Susdiyanto, Saat, dan Ahmad (2009: 27), pembelajaran kontekstual adalah proses pembelajaran yang bertolak dari proses pengaktifan 
pengetahuan yang sudah ada, dalam arti bahwa apa yang akan dipelajari tidak terlepas dari pengetahuan yang sudah dipelajari sebelumnya sehingga pengetahuan yang akan diperoleh siswa adalah pengetahuan yang utuh yang memiliki keterkaitan satu sama lain. Kemudian, Suprijono (2011: 79) menjelaskan bahwa pembelajaran kontekstual atau Contextual Teaching and Learning (CTL) merupakan konsep yang membantu guru mengaitkan antara materi yang diajarkan dengan situasi dunia nyata dan mendorong siswa membuat hubungan antara pengetahuan yang dimilikinya dengan penerapannya dalam kehidupan mereka sebagai anggota keluarga dan masyarakat. Sumiati dan Asra (2009: 14) lebih lanjut mengemukakan bahwa pembelajaran kontekstual merupakan upaya guru untuk membantu siswa memahami relevansi materi pembelajaran yang dipelajarinya, yakni dengan melakukan suatu pendekatan yang memberikan kesempatan kepada siswa untuk mengaplikasikan apa yang dipelajarinya di kelas.

$$
\text { Prinsip pembelajaran }
$$

kontekstual menurut Suprijono (2011: 80-81) adalah sebagai berikut: 1) saling ketergantungan, artinya prinsip ketergantungan merumuskan bahwa kehidupan ini merupakan suatu sistem. Lingkungan belajar merupakan sistem yang mengitegrasikan berbagai komponen pembelajaran dan komponen tersebut saling mempengaruhi secara fungsional. 2) diferensiasi, yakni merujuk pada entitas-entitas yang beraneka ragam dari realitas kehidupan di sekitar siswa. Keanekaragaman mendorong berpikir kritis siswa untuk menemukan hubungan di antara entitasentitas yang beraneka ragam itu. Siswa dapat memahami makna bahwa perbedaan itu rahmat; 3) pengaturan diri, artinya prinsip ini mendorong pentingnya siswa mengeluarkan seluruh potensi yang dimilikinya. Ketika siswa menghubungkan materi akademik dengan konteks keadaan pribadi mereka, siswa terlibat dalam kegiatan yang mengandung prinsip pengaturan diri. Kemudian lebih lanjut Sumiati dan Asra (2009: 18) menjelaskan secara rinci prinsip pembelajaran kontekstual sebagai berikut: 1) menekankan pada pemecaham masalah; 2) mengenal kegiatan mengajar terjadi pada berbagai konteks seperti rumah, masyarakat, dan tempat kerja; 3) mengajar siswa untuk memantau dan mengarahkan belajarnya sehingga menjadi pembelajar yang aktif dan terkendali; 4) menekankan pembelajaran dalam konteks kehidupan siswa; 5) mendorong siswa belajar satu dengan lainnya dan belajar bersamasama; dan 6) menggunakan penilaian otentik.

\section{METODE PENELITIAN}

Jenis penelitian ini tergolong jenis penelitian quiri eksperimen yang diwujudkan dalam bentuk Tindakan Kelas (PTK), dilaksanakan dengan dua siklus, yaitu siklus pertama dilaksanakan di dalam kelas dengan metode mengajar konvensional selama satu bulan (4 kali pertemuan), dan siklus kedua dilakukan di luar kelas melalui pembelajaran kontekstual di kebun percobaan sekolah selama satu bulan (4 kali pertemuan). Tempat penelitian berlangsung di SMK Balla Kecamatan Balla Kabupaten Mamasa. Penelitian ini dilaksanakan antara Bulan Agustus sampai bulan September 2016. Populasi penelitian ini adalah seluruh siswa kelas X sebanyak 18 orang. Teknik pengambilan sampel adalah Sampling Jenuh (Sugiyono, 2011 : 85). Hal ini dilakukan karena populasinya kecil sehingga seluruh populasi 18 orang dijadikan sampel. Data, merupakan hasil tes formatif pembelajaran siklus pertama dan siklus kedua. Teknik Analisis data adalah 
dengan cara deskriptif kualitatif. Alur yang dilalui dalam analisis data kualitatif meliputi penyajian data, membandingkan dengan nilai $\mathrm{KKM}=70$ dan penarikan kesimpulan.

\section{HASIL DAN PEMBAHASAN}

\section{Hasil Penelitian}

Siklus I

Hasil penelitian berupa hasil observasi dapat dilihat pada tabel 1 tentang hasil observasi siklus I sebagai berikut:

Tabel 1 Hasil observasi aktifitas peneliti dalam proses pembelajaran siklus I

\begin{tabular}{|c|c|c|c|c|}
\hline \multirow[b]{2}{*}{ No } & \multirow[b]{2}{*}{ Aspek yang dinilai } & \multicolumn{2}{|c|}{ Kemunculan } & \multirow[b]{2}{*}{ Komentar } \\
\hline & & Ada & $\begin{array}{c}\text { Tidak } \\
\text { ada }\end{array}$ & \\
\hline A & $\begin{array}{l}\text { Kegiatan Awal } \\
\text { 1. Apersepsi } \\
\text { 2. } \text { Menyampaikan tujuan pembelajaran }\end{array}$ & $\begin{array}{l}\sqrt{ } \\
\sqrt{ }\end{array}$ & & $\begin{array}{l}\text { Cukup Baik } \\
\text { Cukup Baik }\end{array}$ \\
\hline B & $\begin{aligned} & \text { Kegiatan Inti } \\
& \text { 1. } \text { Penguasaan materi } \\
& \text { 2. } \text { Penggunaan media/alat peraga/model } \\
& \text { 3. } \text { Mengadakan tanya jawab } \\
& \text { 4. } \text { Penggunaan waktu }\end{aligned}$ & $\begin{array}{l}\sqrt{ } \\
\sqrt{ }\end{array}$ & $\sqrt{ }$ & $\begin{array}{l}\text { Cukup Baik } \\
\text { Cukup Baik } \\
\text { Cukup Baik } \\
\text { Cukup Baik }\end{array}$ \\
\hline $\mathrm{C}$ & $\begin{aligned} \text { Kegiatan } & \text { Akhir } \\
\text { 1. } & \text { Menarik kesimpulan } \\
\text { 2. } & \text { Tes formatif } \\
\text { 3. } & \text { Tindak lanjut }\end{aligned}$ & $\begin{array}{l}\sqrt{ } \\
\sqrt{ } \\
\sqrt{ }\end{array}$ & & $\begin{array}{l}\text { Cukup Baik } \\
\text { Cukup Baik } \\
\text { Cukup Baik }\end{array}$ \\
\hline
\end{tabular}

Model Tabel aktivitas peneliti yang tertera dalam tabel $1 \mathrm{di}$ atas merupakan hasil observasi yang diperoleh peneliti pada saat sedang menyajikan proses pembelajaran pada siklus I. Hasil obsevasi pelaksanaan siklus I menunjukkan aktivitas yang cukup baik walaupun tidak menggunakan media/alat peraga. Tetapi secara umum komponen yang dibutuhkan dalam pelaksanaan proses pembelajaran sudah cukup lengkap.

Selanjutnya hasil Tes formatif yang bertujuan untuk mengetahui tingkat hasil belajar siswa sesuai dengan judul penelitian yang dilakukan setelah proses pembelajaran siklus I berakhir, maka diperoleh data nilai hasil belajar siswa melalui tes formatif siklus I seperti tertera pada tabel 2 berikut:
Tabel 2 Hasil penilaian tes formatif siklus I

\begin{tabular}{|c|l|c|l|}
\hline No & \multicolumn{1}{|c|}{ Nama Siswa } & Nilai & Keterangan \\
\hline 1 & Abner D. & 10 & Tidak tuntas \\
\hline 2 & $\begin{array}{l}\text { Arlin Buntu } \\
\text { Pongko' }\end{array}$ & 32 & tidak tuntas \\
\hline 3 & Asni Bodo' Asi' & 57 & tidak tuntas \\
\hline 4 & Briyan Wahyudi B. & 88 & Tuntas \\
\hline 5 & $\begin{array}{l}\text { Eldin Syaputra } \\
\text { Lodan }\end{array}$ & 77 & Tuntas \\
\hline 6 & $\begin{array}{l}\text { Jhonshon Steel } \\
\text { Saragi }\end{array}$ & 84 & Tuntas \\
\hline 7 & Julianti & 60 & Tidak tuntas \\
\hline 8 & Juniati & 71 & Tuntas \\
\hline 9 & $\begin{array}{l}\text { Mikhael Purwadi } \\
\text { D. }\end{array}$ & 60 & Tidak tuntas \\
\hline 10 & $\begin{array}{l}\text { Natalia Limbong } \\
\text { Lempan }\end{array}$ & 62 & Tidak tuntas \\
\hline 11 & Priska & 75 & Tuntas \\
\hline 12 & Rita Sambo Arruan & 54 & Tidak tuntas \\
\hline 13 & Rivan Kurniawan & 43 & Tidak tuntas \\
\hline 14 & $\begin{array}{l}\text { Silvarianti } \\
\text { Sambolebok }\end{array}$ & 49 & Tidak tuntas \\
\hline 15 & Suprianto D. & 10 & Tidak tuntas \\
\hline 16 & Tonapa' & 43 & Tidak tuntas \\
\hline 17 & Yaser Bembe & 54 & Tidak tuntas \\
\hline
\end{tabular}




\begin{tabular}{|c|c|c|c|}
\hline & Arruan & & \\
\hline 18 & $\begin{array}{l}\text { Zergi Brian Daan } \\
\text { Putra }\end{array}$ & 51 & Tidak tuntas \\
\hline \multicolumn{2}{|c|}{ Jumlah } & 980 & \\
\hline \multicolumn{2}{|c|}{ Rata-rata kelas } & 54,4 & \\
\hline \multicolumn{2}{|c|}{ Tertinggi } & 88 & \\
\hline \multicolumn{2}{|c|}{ Terendah } & 10 & \\
\hline \multicolumn{2}{|c|}{ Persentase Keberhasilan } & $\begin{array}{l}28 \% \\
\text { tuntas } \\
72 \% \\
\text { tidak } \\
\text { tuntas }\end{array}$ & $\begin{array}{l}5 \text { orang } \\
\text { tuntas } \\
13 \text { orang } \\
\text { tidak tuntas }\end{array}$ \\
\hline \multicolumn{2}{|c|}{ KKM } & 70 & \\
\hline
\end{tabular}

Berdasarkan tabel 2 di atas dapat dilihat bahwa yang belum tuntas adalah siswa yang mendapat nilai di bawah Kriteri Ketuntasan Minimal (KKM) sebanyak 13 orang siswa. Sedangkan nilai tuntas yaitu nilai yang sama atau lebih besar dari nilai KKM berada pada rentangan nilai 70 (tujuh puluh) sampai dengan nilai 88 (delapan puluh delapan ) sebanyak 5 (lima) orang siswa. Hasil analisis tersebut dapat dibuat dalam bentuk Chart seperti pada gambar 1. di bawah ini.
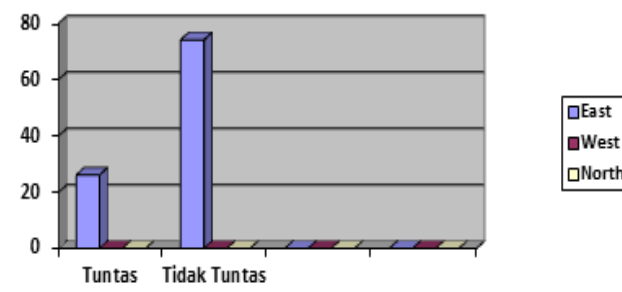

Gambar 1. Chart hasil pembelajaran siklus I

Berdasarkan hasil analisis data di atas merupakan bagian dari refleksi pada siklus I yang memiliki nilai rekomendasi untuk melangkah ke tahap siklus II. Hasil tersebut mendasari keputusan peneliti untuk melakukan tindak lanjut dengan menyiapkan RRP perbaikan untuk siklus II. Karena hasil evaluasi menujukkan bahwa dari 18 orang siswa hanya 5 (lima) orang yang mencapai nilai tuntas dengan persentase $28 \%$ dan terdapat 13 orang siswa yang nilainya tidak mencapai nilai KKM dengan persentase $72 \%$.

Berdasarkan hasil refleksi pada proses pembelajaran siklus I, perlu diadakan perbaikan pembelajaran pada siklus II anatara lain melalui refisi berikut: (1) Guru peneliti perlu memilih metode pembelajaran yang lebih menarik, (2) Guru peneliti perlu melibatkan siswa secara aktif dalam kegiatan pembelajaran, (3) Guru peneliti perlu menggunakan media penyajian yang menarik, tepat dan sesuai dengan materi, dan (4) Guru peneliti perlu waktu seefisien mungkin.

\section{Siklus II}

Pelaksanaan pembelajaran siklus II, dilakukan dengan memilih metode pembelajaran kontekstual pada kegiatan belajar mengajar biologi di kelas $\mathrm{X}$ SMK Balla, guru menilai dan mencatat beberapa hal, tentang aktivitas siswa dalam setiap tahapan belajar, mulai dari tahap kegiatan awal, pelaksanaan pembelajaran, dan kegiatan akhir proses pembelajaran. Dan pada akhirnya melakukan evaluasi untuk menilai hasil belajar apakah ada peningkatan atau tidak.

Hasil penelitian yang diperoleh melalui observasi pada siklus II dapat dilihat pada tabel 3 mengenai proses pembelajaran yang dilakukan oleh guru peneliti sebagai berikut:

Tabel 3 Hasil observasi aktifitas peneliti dalam proses pembelajaran Siklus II

\begin{tabular}{|c|l|l|l|l|}
\hline \multirow{2}{*}{ No. } & \multicolumn{1}{|c|}{ Aspek yang dinilai } & \multicolumn{2}{|c|}{ Kemunculan } & \multirow{2}{*}{ Komentar } \\
\cline { 3 - 4 } & \multicolumn{1}{|c|}{ Ada } & Tidak ada & \multirow{2}{*}{} \\
\hline \multirow{2}{*}{ A } & Kegiatan Awal & $\sqrt{ }$ & & Cukup Baik \\
& 1. Apersepsi & $\sqrt{ }$ & & Cukup Baik \\
\hline
\end{tabular}




\begin{tabular}{|c|c|c|c|c|}
\hline \multirow{2}{*}{ No. } & \multirow{2}{*}{ Aspek yang dinilai } & \multicolumn{2}{|c|}{ Kemunculan } & \multirow{2}{*}{ Komentar } \\
\hline & & Ada & Tidak ada & \\
\hline B & $\begin{array}{l}\text { Kegiatan Inti } \\
\text { 1. Penguasaan Materi } \\
\text { 2. Penggunaan Media kebun percobaan } \\
\text { 3. Mengadakan tanya jawab } \\
\text { 4. Penggunaan waktu }\end{array}$ & $\begin{array}{l}\sqrt{ } \\
\sqrt{ } \\
\sqrt{ } \\
\sqrt{ }\end{array}$ & & $\begin{array}{l}\text { Cukup Baik } \\
\text { Cukup Baik } \\
\text { Cukup Baik } \\
\text { Cukup Baik }\end{array}$ \\
\hline $\mathrm{C}$ & $\begin{array}{l}\text { Kegiatan Akhir } \\
\text { 1. } \quad \text { Menarik Kesimpulan } \\
\text { 2. } \quad \text { Tes formatif } \\
\text { 3. } \quad \text { Tindak lanjut }\end{array}$ & $\begin{array}{l}\sqrt{ } \\
\sqrt{ } \\
\sqrt{ }\end{array}$ & & $\begin{array}{l}\text { Cukup Baik } \\
\text { Cukup Baik } \\
\text { Cukup Baik }\end{array}$ \\
\hline
\end{tabular}

Berdasarkan tabel 3 di atas, aktifitas peneliti selama proses pembelajaran perbaikan siklus II sudah menunjukkan hasil yang baik. Sehingga proses pembelajaran yang telah dilakukan sudah berhasil. Akibatnya data hasil observasi siswa diharapkan menunjukkan prestasi yang lebih baik dari siklus I.

Selanjutnya hasil Tes formatif yang bertujuan untuk mengetahui tingkat hasil belajar siswa sesuai dengan judul penelitian yang dilakukan setelah proses pembelajaran siklus II berakhir, maka diperoleh data nilai hasil belajar siswa melalui tes formatif siklus II seperti tertera pada tabel 4 sebagai berikut

Tabel 4. Hasil penilaian tes formatif

siklus II

\begin{tabular}{|c|l|c|l|}
\hline No & \multicolumn{1}{|c|}{ Nama Siswa } & Nilai & Keterangan \\
\hline 1 & Abner D. & 60 & Tidak tuntas \\
\hline 2 & $\begin{array}{l}\text { Arlin Buntu } \\
\text { Pongko' }\end{array}$ & 80 & Tuntas \\
\hline 3 & Asni Bodo' Asi' & 66 & tidak tuntas \\
\hline 4 & $\begin{array}{l}\text { Briyan Wahyudi } \\
\text { B. }\end{array}$ & 100 & Tuntas \\
\hline 5 & $\begin{array}{l}\text { Eldin Syaputra } \\
\text { Lodan }\end{array}$ & 80 & Tuntas \\
\hline 6 & $\begin{array}{l}\text { Jhonshon Steel } \\
\text { Saragi }\end{array}$ & 84 & Tuntas \\
\hline 7 & Julianti & 70 & Tuntas \\
\hline 8 & Juniati & 70 & Tuntas \\
\hline 9 & $\begin{array}{l}\text { Mikhael } \\
\text { Purwadi D. }\end{array}$ & 70 & Tuntas \\
\hline 10 & Natalia Limbong & 70 & Tuntas \\
\hline
\end{tabular}

\begin{tabular}{|c|c|c|c|}
\hline & Lempan & & \\
\hline 11 & Priska & 66 & Tidak tuntas \\
\hline 12 & $\begin{array}{l}\text { Rita Sambo } \\
\text { Arruan }\end{array}$ & 70 & Tuntas \\
\hline 13 & $\begin{array}{l}\text { Rivan } \\
\text { Kurniawan }\end{array}$ & 90 & Tuntas \\
\hline 14 & $\begin{array}{l}\text { Silvarianti } \\
\text { Sambolebok }\end{array}$ & 70 & Tuntas \\
\hline 15 & Suprianto D. & 80 & Tuntas \\
\hline 16 & Tonapa' & 70 & Tuntas \\
\hline 17 & $\begin{array}{l}\text { Yaser Bembe } \\
\text { Arruan }\end{array}$ & 70 & Tuntas \\
\hline 18 & $\begin{array}{l}\text { Zergi Brian } \\
\text { Daan Putra }\end{array}$ & 94 & Tuntas \\
\hline \multicolumn{2}{|c|}{ Jumlah } & 1.360 & \\
\hline \multicolumn{2}{|c|}{ Rata-rata kelas } & 75,6 & \\
\hline \multicolumn{2}{|c|}{ Tertinggi } & 100 & \\
\hline \multicolumn{2}{|c|}{ Terendah } & 60 & \\
\hline \multicolumn{2}{|c|}{$\begin{array}{l}\text { Persentase } \\
\text { Keberhasilan }\end{array}$} & $\begin{array}{l}83,3 \% \\
\text { tuntas } \\
16,7 \% \\
\text { tidak } \\
\text { tuntas }\end{array}$ & $\begin{array}{l}15 \text { orang } \\
\text { tuntas } \\
3 \text { orang tidak } \\
\text { tuntas }\end{array}$ \\
\hline \multicolumn{2}{|c|}{ KKM } & 70 & \\
\hline
\end{tabular}

Berdasarkan tabel 4 di atas dapat dilihat bahwa yang belum tuntas adalah siswa yang mendapat nilai di bawah Kriteri Ketuntasan Minimal (KKM) sebanyak 3 orang siswa (16,7 $\%)$. Sedangkan nilai tuntas yaitu nilai yang sama atau lebih besar dari nilai KKM berada pada rentangan nilai 70 sampai dengan nilai 100 sebanyak 15 (enam) orang siswa $(83,3 \%)$. Hasil analisis tersebut dapat dibuat dalam bentuk Chart seperti pada gambar 2 di bawah ini. 


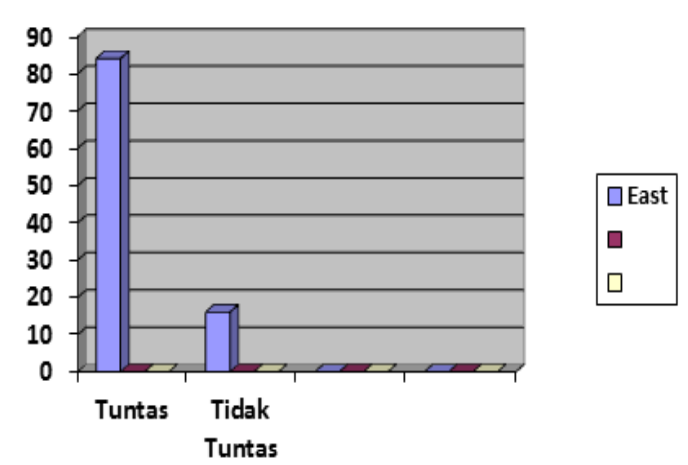

Gambar 2. Chart hasil pembelajaran siklus II

Berdasarkan hasil analisis data di atas merupakan bagian dari refleksi pada siklus II. Hasil tersebut memberi keyakinan kepada penelitian tentang penerapan metode pembelajaran Kontekstual bahwa metode tersebut terbukti dapat meningkatkan hasil pembelajaran siswa, karena hasil evaluasi menujukkan bahwa dari 18 orang siswa yang ikut pada siklus II, sisa 3 orang yang nilainya tidak mencapai nilai KKM dengan persentase $16,7 \%$ dan yang mencapai nilai tuntas 15 orang dengan persentase $83,3 \%$.

Hasil evaluasi pada siklus I dan siklus II proses pembelajaran yang berlangsung pada kelas X SMK Balla, peningkatan persentase yang diperoleh siswa dalam ketuntasan belajar pokok bahasan Pertumbuhan Tanaman mata pelajaran Biologi dapat dilihat pada tabel 5 di bawah ini.

Tabel 5. Peningkatan hasil belajar siswa pada pokok bahasan Pertumbuhan Tanaman mata pelajaran Biologi Kelas X SMK Balla pada siklus I dan II.

\begin{tabular}{|c|c|c|c|}
\hline \multirow{2}{*}{ No. } & Nilai & Siklus & Siklus \\
\cline { 3 - 4 } & Indikator & I & II \\
\hline 1 & $0-69$ & $.72 \%$ & $16,7 \%$ \\
\hline 2 & $70-100$ & $28 \%$ & $83,3 \%$ \\
\hline
\end{tabular}

Peningkatan pada tiap indikator di atas dapat menjawab rumusan masalah, yaitu dengan menerapkan metode pembelajaran Kontekstual dapat meningkatkan hasil belajar siswa pada pokok bahasan Pertumbuhan Tanaman mata pelajaran Biologi SMK Balla Kecamatan Balla Kabupaten Mamasa.

\section{Pembahasan}

Setelah merefleksi kegiatan siklus I, peneliti melakukan perbaikan, terutama menjelaskan langkah-langkah pelaksanaan Strategi pembelajaran Kontekstual. Hasil refleksi diimplementasikan mulai dari perencanaan, pelaksanaan, pengamatan (observasi) sampai pada analisis hasil observasi. Melalui refleksi peneliti dapat melihat kekurangan-kekurangan pelaksanaan siklus I, terutama hasil yang diperoleh dari kegiatan pembelajaran siklus I, baik aktivitas maupun hasil belajar siswa, masih berada pada level yang sangat rendah. Dari total 18 orang siswa sebagai sampel penelitian ternyata yang memperoleh nilai tuntas hanya 5 orang siswa (28\%) dan sisanya 13 orang siswa $(72 \%)$ belum memperoleh nilai tuntas.

Hal tersebut kemungkinan disebabkan oleh proses pembelajaran Konvensional pada siklus I. Oleh sebab itu, pelaksanaan pada siklus I ini, masih didominasi oleh guru. Jadi pelaksanaannya cenderung bersifat satu arah, sehingga pendapat Zamroni (2000: 25) yang kuatir akan pembelajaran yang bersifat satu arah dari guru karena akan membangun iklim sekolah yang otoriter atau tidak demokratis, dan memberi efek pada sekolah yang menjadi statis dan beku bahkan akan memberi efek destruktif bagi sekolah sebagai taman pesemaian putera-puteri calon intelektual bangsa di masa depan. Sebaliknya diharapkan bahwa proses pembelajaran yang ideal adalah dengan melibatkan siswa seutuhnya dalam proses pembelajaran. 
Inilah beberapa catatan yang terjadi dan merupakan refleksi dan evaluasi pada siklus I, sehingga diharapkan pelaksanaan siklus II akan lebih baik.

Pelaksanaan siklus II, mengalami peningkatan sebagai efek dari perbaikan-perbaikan yang dilakukan, terutama dengan mengubah metode proses pembelajaran yang lebih kontekstual di kebun percobaan yang menjadi inti dari perbaikan proses pembelajaran.

Hasil yang diperoleh dari kegiatan pembelajaran siklus II, baik aktivitas maupun prestasi belajar siswa, mengalami peningkatan, utamanya prestasi belajar siswa lebih meningkat. Dari 18 orang siswa sebagai sampel penelitian, yang aktif pada siklus II ini, ternyata yang memperoleh nilai tuntas telah meningkat menjadi 15 orang siswa $(83,3 \%)$ dan sisanya 3 orang siswa $(16,7 \%) \quad$ yang belum memperoleh nilai tuntas.

Pemberian makna terhadap obyek dan pengalaman oleh siswa tidak dilakukan secara sendiri-sendiri oleh siswa, melainkan melalui interaksi dalam jaringan sosial yang unik, yang terbentuk baik dalam budaya kelas maupun di luar kelas. Oleh sebab itu pengelolaan pembelajaran harus diutamakan pada pengelolaan siswa dalam memproses gagasannya, bukan semata-mata pada pengelolaan siswa dan lingkungan belajarnya bahkan pada unjuk kerja atau perstasi belajarnya yang dikaitkan dengan sistem penghargaan dari luar sepertai nilai, ijazah, dan sebagainya.

\section{PENUTUP}

\section{Kesimpulan}

Berdasarkan hasil penelitian dan pembahasan di atas, kesimpulan yang dapat ditarik dalam penelitian ini adalah:
1. Langkah-langkah penggunaan proses pembelajaran Kontekstual untuk meningkatkan aktivitas dan hasil belajar siswa pada pokok bahasan Pertumbuhan Tanaman mata pelajaran Biologi siswa kelas $\mathrm{X}$ SMK Balla Kabupaten Mamasa, meliputi: (1) menyusun rencana sesuai dengan ketentuan, (2) melaksanakan sesuai dengan rencana, (3) mengevaluasi kemampuan siswa dalam memenuhi setiap tuntutan pembelajaran, dan (4) menindaklanjuti hasilnya dengan cermat.

2. Peningkatan aktivitas dan hasil belajar siswa terjadi secara bertahap, terlihat dalam beberapa hal seperti: partisipasi, minat, dan kemampuan serta peningkatan hasil belajarnya, ditunjukkan siswa dalam hasil belajar siklus I yang masih jauh dari harapan, (hanya $28 \%$ ) yang tunas, namun mengalami peningkatan pada siklus II sebesar $83,3 \%$ yang tuntas dan sisa $16,7 \%$ yang belum tuntas.

Dengan demikian, simpulan utama dari penelitian ini bahwa penggunaan metode pembelajaran Kontekstual terbukti dapat meningkatkan aktivitas dan hasil belajar siswa pada pokok bahasan Pertumbuhan Tanaman mata pelajaran Biologi siswa kelas X SMK Balla Kabupaten Mamasa.

\section{Saran}

Berdasarkan pengalaman mengajar dan hasil yang diperoleh dalam penelitian ini, disarankan kepada rekan-rekan guru agar :

1. Senantiasa melakukan inovasi dalam proses pembelajaran, dengan cara tidak monoton pada metode klasik yang selama ini kita gunakan, melainkan berusaha 
mencoba mempergunakan berbagai metode pembelajaran sehingga anak didik tidak merasa bosan, dan senantiasa membangkitkan suasana baru dalam belajar yang pada gilirannya dapat meningkatkan hasil belajar siswa.

2. Dengan penggunaan berbagai metode, juga menguntungkan bagi kita karena kita sendiri tidak bosan dengan rutinitas keseharian mengajar, sebab dengan berbagai metode yang diterapkan senantiasa memberi nuansa baru, disamping menguntungkan dari segi PTK sebagai tuntutan bagi profesi guru sebagai salah satu persyaratan utama untuk naik pangkat.

\section{DAFTAR PUSTAKA}

Jumnati. 2013. Peningkatan Hasil Belajar Siswa Kelas III SD Negeri 2 Sukajaya dalam Pembelajaran IPS Melalui Penggunaan Model Quantum Teaching dan Snowball Throwing. /10/peningkatanhasil-belajar-siswa-kelas.html

Roestiyah,(2000: 58,; 2006: 106) belajar pembelajaran

Sugiyono. 2011. Metode Penelitian Kuantitatif Kualitatif dan $R$ $\& D$. Bandung: Alfabeta.

Sumiati dan Asra. 2009. Metode Pembelajaran. Bandung: CV Wacana Prima.

Suprijono, Agus. 2011. Cooperatif Learning, Teori dan Aplikasi PAIKEM. (Cet. V). Yogyakarta: Pustaka Pelajar.

Susdiyanto, Saat, dan Ahmad. 2009. Strategi Pembelajaran.
(Modul Pendidikan dan

Latihan Profesi Guru).

Makassar: Panitia Sertifikasi

Guru Agama Rayon LPTK

Fakultas Tarbiyah dan

Keguruan UIN Alauddin

Makassar.

Zamroni. 2000. Paradigma Pendidikan Masa Depan. Yogyakarta: Bigraf Publishing 